\title{
THE USE OF PELLET SCREENINGS IN THE SINTERING PROCESS
}

\author{
Helio Cardoso Pereira ' \\ Philippe Rocha Santos Souto ' \\ Antonio Eduardo Clark Peres ${ }^{2}$ \\ Volker Johan Ritz ${ }^{3}$
}

\begin{abstract}
With the progressive deterioration in iron ore quality worldwide in recent years, steelmakers need to seek alternatives to mitigate the deficiency of this raw material. Investments in the use of high grade concentrate and the application of pre-agglomeration technologies are alternatives to make up for this deficit without affecting the utilization in the sintering process. As a possibility to avoid such investment, pellet screenings in comparison with the current natural sinter feed that can be found in the market, presents advantages such as low alumina and silica contents, but also low loss on ignition (LOI) and suitable particle size distribution. Sintering tests were performed at the SGA (Studiengesellschaft für Eisenerzaufbereitung) laboratory in Germany to evaluate the performance of this product when added to typical sintering mixtures used in Western Europe. The test results showed gains in the chemical, physical and metallurgical quality of the sinter produced.
\end{abstract}

Keywords: Sintering process; Sinter feed; Iron ore mixtures; Pellet screenings.

\section{O USO DE PELLET SCREENINGS NO PROCESSO DE SINTERIZAÇÃO}

\section{Resumo}

Com a deteriorização progressiva da qualidade do minério de ferro em todo o mundo nos anos recentes, fabricantes de aço precisam buscar alternativas para mitigar a escassez de sinter feed de alto teor. Investimentos no uso de concentrados de alto teor e a aplicação de tecnologias de pré-aglomeração são alternativas para suprir essa deficiência. Como possibilidade para evitar tais investimentos onerosos, o pellet screenings, em comparação com o sinter feed natural atualmente disponível no Mercado, apresenta vantagens tais como baixos teores de alumina e sílica, baixo nível de perda ao fogo e distribuição de tamanho de partículas adequado. Ensaios de sinterização foram executados no laboratório SGA (Studiengesellschaft für Eisenerzaufbereitung), na Alemanha, para avaliar o desempenho desse produto quando adicionado a misturas típicas de sinterização usadas na Europa Ocidental. Os resultados mostraram ganhos de qualidade química, física e metalúrgica do sínter produzido.

Palavras-chave: Processo de sinterização; Sinter feed; Misturas de minérios de ferro; Pellet screenings.

\section{INTRODUCTION}

\section{I.I World Steel Scenario}

Lüngen et al. [I] stated that recently the global steel industry has been facing a major challenge with the deterioration of chemical and particle size quality of the sinter feed offered in the market. This scenario forces the steel industry to seek alternatives to maintain the quality of sinter to feed the blast furnace. Among them, we can mention the use of high grade concentrates and pellet feed to improve the chemical composition. However, this application is limited due to the increased amount of fines, which increases the difficulty to granulate the mixture to be sintered.

According to Noldin Jr [2], in order to increase the portion of pellet feed and concentrate in the mixture to be sintered, it might be necessary to change the layout of the

'Samarco Mineração S/A, Ponta Ubu, ES, Brazil.

${ }^{2}$ Departamento de Engenharia Metalúrgica e de Materiais - DEMET, Escola de Engenharia - EE, Universidade Federal de Minas Gerais - UFMG,

Belo Horizonte, MG, Brazil. E-mail: aecperes@demet.ufmg.com.br

${ }^{3}$ Studiengesellschaft für Eisenerzaufbereitung SGA, Liebenburg-Othfresen, Germany.

2176-I523 (C) 2017 Associação Brasileira de Metalurgia, Materiais e Mineração. Published by ABM. This is an open access paper, published under the Creative Commons CC BY-NC-ND license (Attribution-NonCommercial-NoDerivs) - https://creativecommons.org/licenses/ by-nc-nd/4.0/. 
production process, for example, making adjustments in the dosage system and installing both intensive mixers and granulators. These changes require high investment and possible downtime to fit the new layout.

The final stage of iron ore pellets production consists of screening. The oversize fraction is ready for the market and the undersize fraction, designated as pellet screenings (PS), is a product with low contaminants content (alumina and silica), low loss on ignition (LOI) and particle size distribution suitable for the sintering process [3].

\subsection{The Effect of Granulation in the Sintering Process}

Granulation is an important step in the sintering process. During this stage, fine particles adhere to the coarse particles, or fine particles agglomerate to form appropriate size grains $[4,5]$.

Effective granulation directly affects the permeability of the sintering bed. With improved permeability, there is an increase in gas flow and, consequently, in sintering speed, promoting better gas-solid heat transfer and leading to increased productivity and lower energy consumption [6].

\section{I.3 The Effect of Alumina in the Sintering Process}

The presence of alumina increases the viscosity of the primary melt formed during the sintering process, leading to a weaker sinter structure with more irregular interconnected pores [7]. Therefore, the RDI is reported to deteriorate markedly as the alumina content increases. Industrial tests at Thyssen in 1984 showed that a $1 \%$ rise in the sinter alumina content increased RDI by 2 points $[7,8]$.

\section{I.4 The effect of $\mathrm{CaO} / \mathrm{SiO}_{2}$ in the Sintering Process}

Previous studies showed that in the range of I.78-1.93, an increase of 0.1 in the $\mathrm{CaO} / \mathrm{SiO}_{2}$ ratio results in a $3 \%$ rise in the tumble index. With a rising $\mathrm{CaO} / \mathrm{SiO}_{2}$ ratio, the formation of fayalithe, which is difficult to reduce, is repressed [9]. An increase in basicity $\left(\mathrm{CaO} / \mathrm{SiO}_{2}\right)$ favours the formation of calcium ferrite and densification of the bond at low sintering temperatures [10].

\section{I.5 The Effect of Loss on Ignition (LOI) in the Sintering Process}

Iron ore with lower loss on ignition directly affects the sintering process, reducing fuel consumption and increasing productivity and sinter physical strength [I I].

\section{EXPERIMENTAL PROCEDURES}

\section{I Raw Materials}

For this study a typical European sintering mixture was tested with varied portions of the pellet screenings (PS) and other ores, as well as the additives that were taken from the SGA stock. This mixture was composed of a high portion of Brazilian sinter fines, as well as concentrates and some blast furnace screened return fines. The chemical analyses and size distribution are listed in Tables I and 2.

Figure I shows graphically the favorable size distribution of the pellet screenings, which is coarser than the other ores.

For the adjustment of the sinter chemistry, limestone, olivine and sand were used. During the study, burnt lime was added to improve sintering performance at $0.8 \%$.

A total of 5 sintering series were performed for this study. Table 3 shows the proportion of the mixture tested.

\subsection{Sintering Conditions and Target Analysis of the Sinters}

The sintering tests were performed in the SGA pot grate unit. The following conditions were applied to all sinter tests:

- pot grate $\varnothing 450 \mathrm{~mm}$, height $600 \mathrm{~mm}$;

- bed height: $520 \mathrm{~mm}$, including $20 \mathrm{~mm}$ hearth layer;

- ignition time: $90 \mathrm{~s}$;

- ignition temperature: $1,220^{\circ} \mathrm{C}$;

- ignition suction: increasing from 40 mbar to 160 mbar;

- sintering suction: 160 mbar.

For each series, initial tests were performed to adjust a balanced return fines ratio of $0.95-1.05$.

Table I. Chemical composition of the iron ore types used in the sintering mixture

\begin{tabular}{|c|c|c|c|c|c|c|}
\hline $\begin{array}{c}\text { Chemical Analysis } \\
\%\end{array}$ & $\begin{array}{c}\text { Brazilian Sinter } \\
\text { Feed I }\end{array}$ & $\begin{array}{c}\text { Brazilian Sinter } \\
\text { Feed } 2\end{array}$ & BF Return Fines & $\begin{array}{c}\text { Canadian } \\
\text { Concentrate }\end{array}$ & $\begin{array}{c}\text { African } \\
\text { Concentrate }\end{array}$ & $\begin{array}{c}\text { Pellet } \\
\text { Screenings }\end{array}$ \\
\hline $\mathrm{Fe}$ & 65.32 & 63.79 & 56.01 & 65.64 & 65.36 & 67.26 \\
\hline $\mathrm{FeO}$ & 0.20 & 0.76 & 7.86 & 11.26 & 26.88 & 0.29 \\
\hline $\mathrm{SiO}_{2}$ & 2.42 & 5.47 & 5.33 & 4.39 & 7.26 & 1.76 \\
\hline $\mathrm{Al}_{2} \mathrm{O}_{3}$ & 1.14 & 0.78 & 1.44 & 0.18 & 0.55 & 0.51 \\
\hline LOI & 1.82 & 1.69 & 0.53 & 1.64 & 0.38 & 0.41 \\
\hline
\end{tabular}


Pereira et al.

Table 2. Size distribution of the iron ore types used in the sintering mixture

\begin{tabular}{|c|c|c|c|c|c|c|}
\hline $\begin{array}{c}\text { Size } \\
(\mathrm{mm})\end{array}$ & $\begin{array}{c}\text { Brazilian Sinter } \\
\text { Feed I }\end{array}$ & $\begin{array}{c}\text { Brazilian Sinter } \\
\text { Feed } 2\end{array}$ & BF Return Fines & $\begin{array}{c}\text { Canadian } \\
\text { Concentrate }\end{array}$ & $\begin{array}{c}\text { African } \\
\text { Concentrate }\end{array}$ & Pellet Screenings \\
\hline$+10,0$ & $0.6 / 0.6$ & $1.6 / 1.6$ & $0.0 / 0.0$ & $0.0 / 0.0$ & $0.1 / 0.1$ & $0.0 / 0.0$ \\
\hline$+8,0$ & $7.6 / 8.2$ & $5.0 / 6.6$ & $0.3 / 0.3$ & $0.0 / 0.0$ & $0.0 / 0.1$ & $0.5 / 0.5$ \\
\hline+6.3 & $3.4 / 11.6$ & $5.9 / 12.5$ & $10.2 / 10.5$ & $0.0 / 0.0$ & $0.1 / 0.2$ & $8.4 / 8.9$ \\
\hline+5.0 & $5.1 / 16.7$ & $6.4 / 19.0$ & $27.3 / 37.8$ & $0.0 / 0.0$ & $0.1 / 0.3$ & $0.0 / 8.9$ \\
\hline+4.0 & I.I / 17.8 & $2.1 / 21.1$ & $13.5 / 5 \mid .3$ & $0.0 / 0.0$ & $0.0 / 0.3$ & $0.0 / 8.9$ \\
\hline+3.15 & $7.4 / 25.2$ & $7.0 / 28.1$ & $12.7 / 64.0$ & $0.0 / 0.0$ & $0.1 / 0.4$ & $42.9 / 51.8$ \\
\hline+2.5 & $9.5 / 34.7$ & $8.0 / 36.1$ & $14.6 / 78.6$ & $0.1 / 0.1$ & I.I / I.5 & $0.0 / 51.8$ \\
\hline+1.0 & $12.3 / 47.0$ & $8.2 / 44.3$ & $9.7 / 88.3$ & $2.1 / 2.2$ & $7.3 / 8.8$ & $20.4 / 72.2$ \\
\hline+0.5 & $7.6 / 54.6$ & $5.2 / 49.5$ & $4.8 / 93.1$ & 5.4 / 7.6 & $13.6 / 22.4$ & $2.3 / 74.5$ \\
\hline+0.315 & $7.1 / 61.7$ & $3.1 / 52.6$ & $2.2 / 95.3$ & $13.9 / 21.5$ & $14.0 / 36.4$ & $0.9 / 75.4$ \\
\hline+0.200 & $5.9 / 67.6$ & $5.1 / 57.7$ & $1.5 / 96.8$ & $21.9 / 43.4$ & $14.8 / 51.2$ & $0.9 / 76.3$ \\
\hline+0.160 & $2.9 / 70.5$ & $3.6 / 61.3$ & $0.0 / 96.8$ & $0.0 / 43.4$ & $0.0 / 51.2$ & $0.0 / 76.3$ \\
\hline+0.100 & $4.6 / 75.1$ & $7.5 / 68.8$ & $1.4 / 98.2$ & $37.1 / 80.5$ & $19.2 / 70.4$ & $1.2 / 77.5$ \\
\hline+0.063 & $3.0 / 78.1$ & $0.6 / 69.4$ & $0.4 / 98.6$ & $14.3 / 94.8$ & 9.4 / 79.8 & $1.3 / 78.8$ \\
\hline+0.040 & 1.7 / 79.8 & $16.7 / 86.1$ & $0.3 / 98.9$ & 3.4 / 98.2 & $6.1 / 85.9$ & $2.8 / 81.6$ \\
\hline+0.025 & $2.5 / 82.3$ & $4.6 / 90.7$ & 0.2 / 99.1 & $0.6 / 98.8$ & $4.3 / 90.2$ & $5.1 / 86.7$ \\
\hline+0 & $17.7 / 100.0$ & $9.3 / 100.0$ & $0.9 / 100.0$ & $1.2 / 100.0$ & $9.8 / 100.0$ & $13.3 / 100.0$ \\
\hline D-80 & 3.748 & 4.509 & 5.848 & 0.334 & 0.589 & 5.485 \\
\hline HS-50 & 0.800 & 0.470 & 4.098 & 0.149 & 0.209 & 3.280 \\
\hline
\end{tabular}

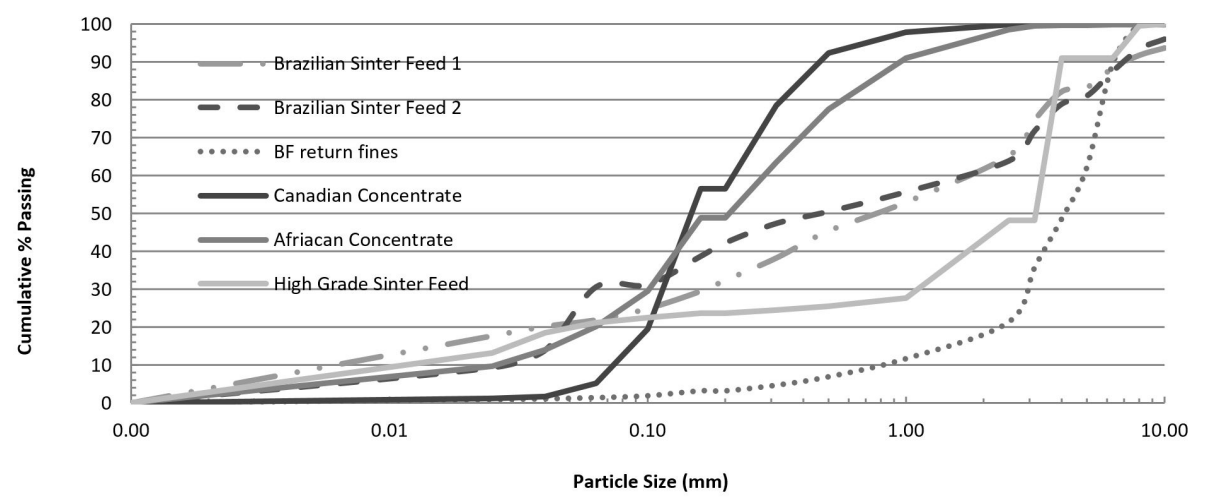

Figure I. Size distribution of the ores used in the sintering mixture.

Table 3. Iron ore proportion of the sintering mixture

\begin{tabular}{cccccccc}
\hline Sinter Series & $\begin{array}{c}\text { Brazilian Sinter } \\
\text { Feed I }\end{array}$ & $\begin{array}{c}\text { Brazilian Sinter } \\
\text { Feed 2 }\end{array}$ & BF Return Fines & $\begin{array}{c}\text { Canadian } \\
\text { Concentrate }\end{array}$ & $\begin{array}{c}\text { African } \\
\text { Concentrate }\end{array}$ & $\begin{array}{c}\text { Pellet } \\
\text { Screenings }\end{array}$ \\
\hline I & 40 & 35 & 10 & 8 & 7 & - \\
2 & 36 & 31.5 & 9 & 7.2 & 6.3 & 10 \\
3 & 32 & 28 & 8 & 5.4 & 4.6 & 20 & 30 \\
4 & 28 & 24.5 & 7 & 4.6 & 4.2 & 40 \\
5 & 24 & 21 & 6 & 4.8 & & \\
\hline
\end{tabular}

At a balanced return fines ratio and correct $\mathrm{FeO}$-content, the sinter feed moisture was varied to achieve optimum productivity.

For the sintering tests, the ore blends preparation sequence was: mixing of ores and additives in a Cyclos mixer for $4 \mathrm{~min}$ at natural moisture; adding water; mixing for another 2 minutes; rerolling in a drum for 3 min (the drum used here was a conventional cement mixer drum type; however no mixing tools shovels were used, but the device was equipped with $2 \mathrm{~cm}$ wide lifters; sinter treatment for return fines generation: tumbling (70 revolutions); return fines screening: $6.3 \mathrm{~mm}$.

The target chemical analyses for the species the final sinter were set at the values presented in Table 4. 
The sinters produced were tested for the metallurgical and physical properties, including tumbler strength [12], low temperature reduction degradation indices-RDI [13] and reducibility by the rate of reduction index [14].

\section{RESULTS}

\section{I Evaluation of Sintering Mixtures}

The effect of adding the HGSF to the ore mixture is quite impressive. This addition has a very positive effect on the chemistry, because it increases the Fe content and distinctly decreases the $\mathrm{SiO}_{2}$ and $\mathrm{Al}_{2} \mathrm{O}_{3}$ content as well as the LOI. Moreover, the $\mathrm{CaO}$ content is higher than the other ores, with the exception of $\mathrm{BF}$ fines, which requires less amount of limestone to maintain the sinter basicity. The use of pellet screenings improves the chemistry of the sinter and can be used to compensate for the disadvantageous chemistry of other fines grades. Table 5 lists the calculated analysis of the European mixture with the addition rate up to $40 \%$ of the pellet screenings and proportional dilution of the other ores. For this calculation, only the analyses of the ores were considered; additives were not taken into account.

Figure 2 shows that the size distribution of the ore mixture is affected positively, due to the increased proportion of nuclei particles and decreased proportion of intermediate particles.

\subsection{Evaluation of Sintering Performance}

The average sintering productivity distinctly increases from 35 to $4 \mathrm{It} / \mathrm{m}^{2} / 24 \mathrm{~h}$ as well as the flame speed from 20.3 to $23.7 \mathrm{~mm} / \mathrm{min}$, when one adds $40 \%$ of pellet screenings. The coke breeze rate improves from 64.5 to $62.0 \mathrm{~kg} / \mathrm{t}$ final sinter. These results are graphically displayed in Figures 3 and 4 . These figures clearly demonstrate the very positive effect of the pellet screenings, both for sintering productivity as well as for coke breeze consumption.

\subsection{Characterization of the Sinters Produced}

From each series, the sinter that achieved the optimum productivity was chosen for the chemical, physical and metallurgical tests.

The sinters were controlled at the same levels of basicity, $\mathrm{SiO}_{2}, \mathrm{MgO}$ and $\mathrm{FeO}$, but the $\mathrm{Al}_{2} \mathrm{O}_{3}$ content varied with the mixture of the iron ores, as shown in Table 6.

Tumble strength (ISO 327I: 2007) slightly increased by approximately I.5-2.0\%, when the HGSF was added to the mixture. This result could be even improved if the productivity had remained at the same level as reference series. This is displayed graphically in Figure 5. The figure also demonstrates that sinter abrasion was not affected.

The addition of pellet screenings did not affect the reducibility of the sinters (ISO 4695:2007), as shown in Figure 6.

All sinters produced reached good RDI results (ISO 4696-I:2007). As shown in Figure 7, when $40 \%$ of pellet screenings was added, these results were slightly improved, most probably due to the decreased sinter $\mathrm{Al}_{2} \mathrm{O}_{3}$ content.

Table 4. Target chemical analyses for the species in the final sinter

\begin{tabular}{cccccc}
\hline Species & Fe & FeO & $\mathrm{SiO}_{2}$ & $\mathbf{M g O}$ & $\mathrm{CaO}_{\mathbf{S i O}}$ \\
\hline Content (\%) & $\sim 56.3$ & $7.5 \pm 0.5$ & $5.9 \pm 0.2$ & $1.0 \pm 0.2$ & $1.95 \pm 0.1$ \\
\hline
\end{tabular}

Table 5. Chemical composition of the sintering mixture series

\begin{tabular}{|c|c|c|c|c|c|}
\hline Chemical Analysis & Reference Series & $10 \%$ PS & $20 \%$ PS & $30 \%$ PS & $40 \%$ PS \\
\hline $\mathrm{Fe}(\%)$ & 63.88 & 64.22 & 64.55 & 64.89 & 65.22 \\
\hline $\mathrm{FeO}(\%)$ & 3.91 & 3.55 & 3.19 & 2.83 & 2.46 \\
\hline $\mathrm{SiO}_{2}(\%)$ & 4.27 & 4.02 & 3.77 & 3.52 & 3.27 \\
\hline $\mathrm{Al}_{2} \mathrm{O}_{3}(\%)$ & 0.93 & 0.88 & 0.84 & 0.80 & 0.76 \\
\hline LOI (\%) & 1.53 & 1.53 & 1.31 & 1.20 & 1.08 \\
\hline
\end{tabular}

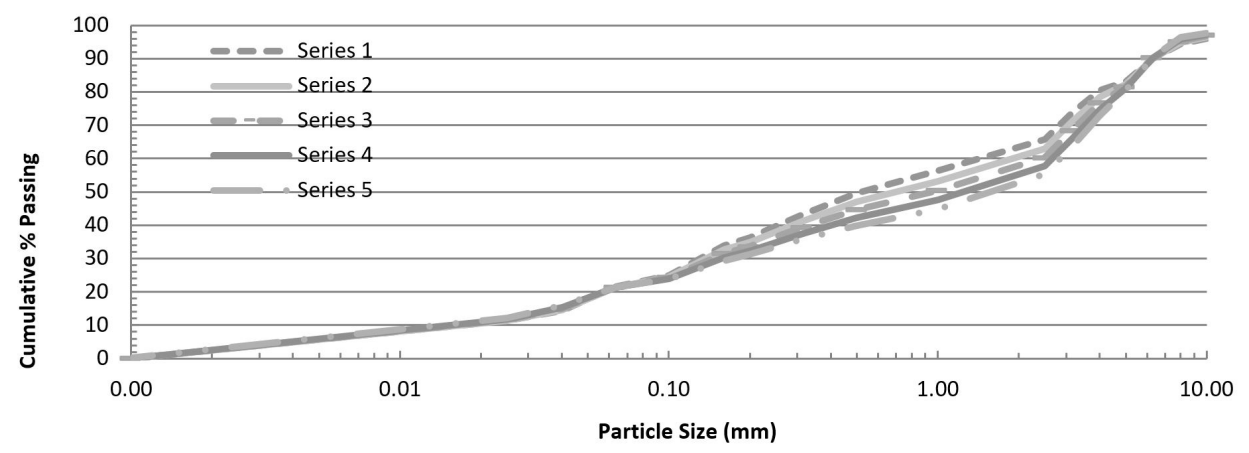

Figure 2. Size distribution of the sintering mixture series. 


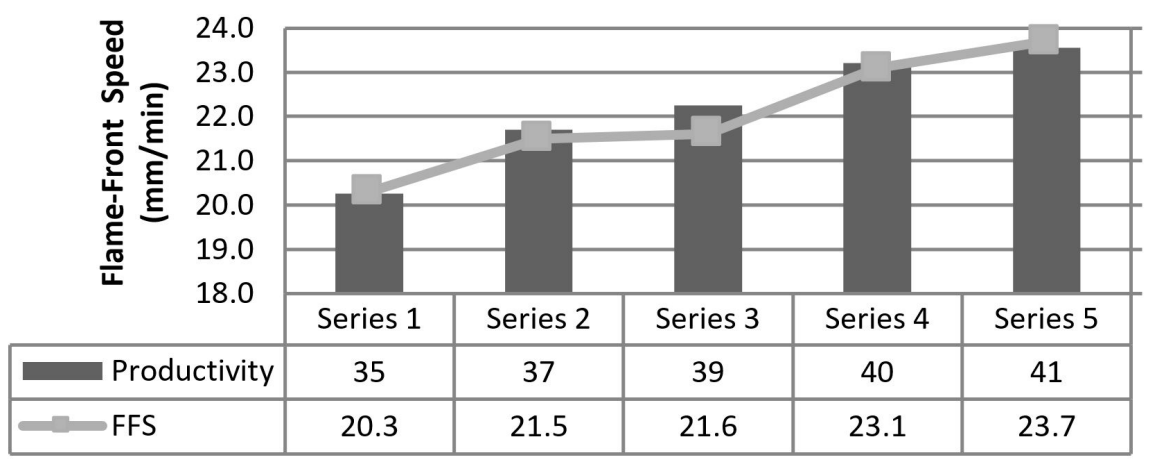

42.0

40.0

38.0

36.0

34.0

32.0

Figure 3. Sinter series productivity and flame-front speed.

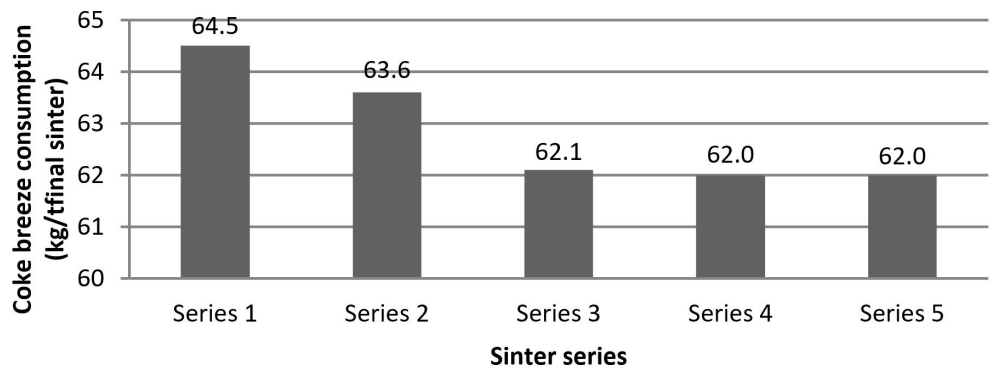

Figure 4. Sinter series coke breeze consumption.

Table 6. Chemical composition of the sinters produced

\begin{tabular}{|c|c|c|c|c|c|}
\hline Chemical Analysis & Series I & Series 2 & Series 3 & Series 5 & Series 6 \\
\hline $\mathrm{Fe}(\%)$ & 56.23 & 56.25 & 56.24 & 56.23 & 56.36 \\
\hline $\mathrm{FeO}(\%)$ & 7.30 & 7.33 & 7.25 & 7.35 & 7.07 \\
\hline $\mathrm{SiO}_{2}(\%)$ & 5.89 & 5.99 & 5.99 & 6.04 & 5.94 \\
\hline $\mathrm{Al}_{2} \mathrm{O}_{3}(\%)$ & 1.14 & 1.06 & 1.04 & 0.99 & 0.95 \\
\hline Basicity & 1.97 & 1.94 & 1.93 & 1.93 & 1.95 \\
\hline
\end{tabular}

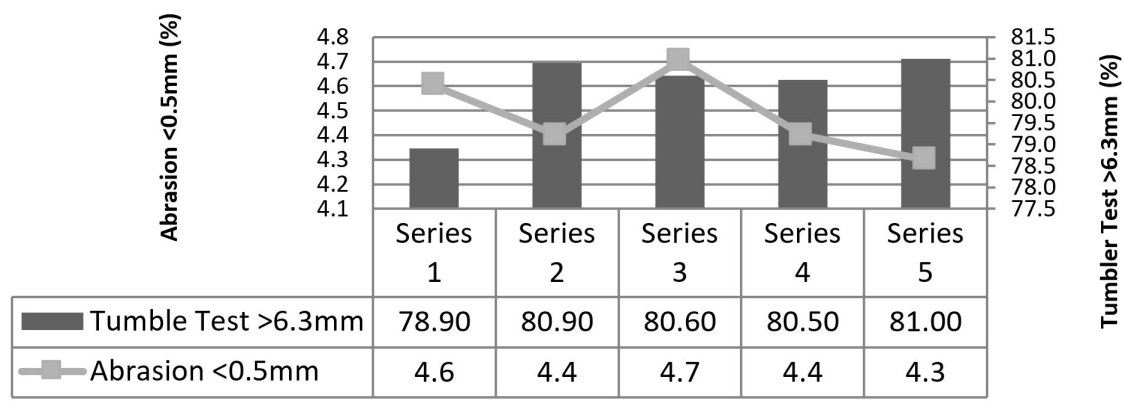

Figure 5. Sinter series tumbler strength.

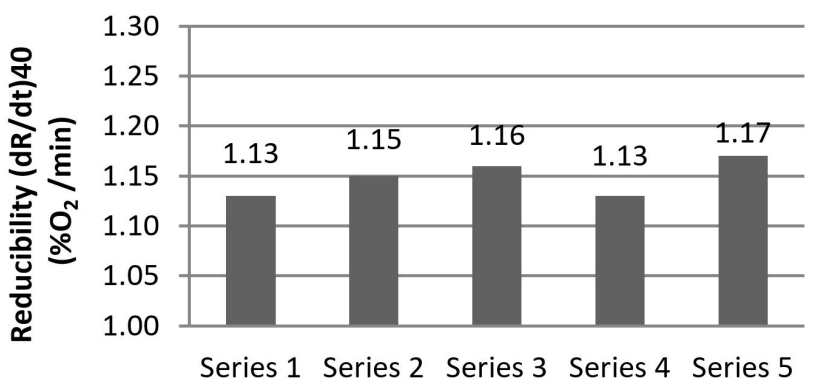

Sinter series

Figure 6. Sinter series reducibility.

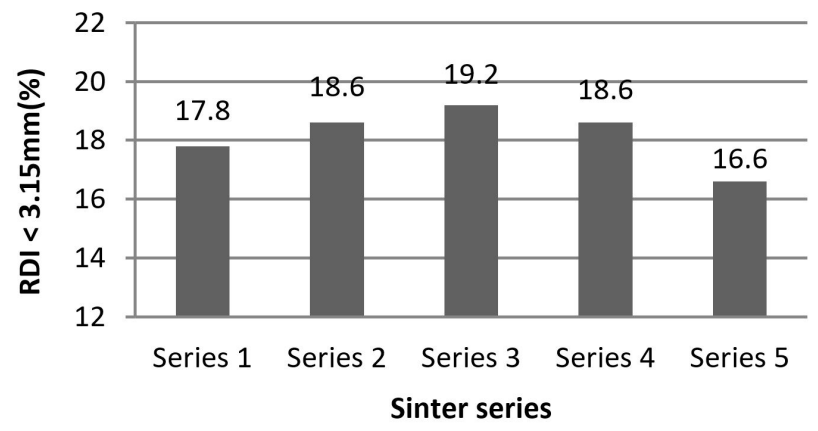

Figure 7. Sinter series $\mathrm{RDI}<3.15 \mathrm{~mm}$. 


\section{CONCLUSIONS}

The test confirmed that the increase in productivity is proportional to the ratio of pellet screenings in the sinter blend. At the same time, the coke breeze ratio decreased. The chemical analysis of the pellet screenings is very clean, with high iron and low gangue contents, which enables mixture users to both improve sinter chemistry and reduce limestone consumption or to compensate for the disadvantage of other fines grades. Reducibility of the sinters was not affected by adding the pellet screenings to the European blend. Nevertheless, slight improvement was observed in the disintegration behavior when a high portion of pellet screenings is added to the mixture, most probably due to its lower alumina content.

\section{Acknowledgements}

The authors are grateful to the institutions Samarco Mineração, CAPES (Coordenação de Aperfeiçoamento de Pessoal de Nível Superior). CNPq (Conselho Nacional de Desenvolvimento Científico e Tecnológico), CAPES-PROEX (Programa de Excelência Acadêmica) and FAPEMIG (Fundação de Amparo à Pesquisa do Estado de Minas Gerais) for supporting the investigation.

\section{REFERENCES}

I Lüngen HB, Peters M, Schmöle P. Iron making in Western Europe. In: METEC InSteelCon. Plenary Session 6th ECIC; 20I I June 27-July I; Düsseldorf, Germany. Düsseldorf: METEC; 20I I. p. I5-24.

2 Noldin Jr JH, Lüngen HB, Schmöle P. Trends in Iron Making given the new reality in iron ore and coal resources. In: METEC \& $2^{\text {nd }}$ Estad. Proceedings of Blast Furnace Ironmaking Overview; 2015 June 16-20; Düsseldorf, Germany. Düsseldorf; p. I35-|42.

3 Pereira HC. Avaliação em escala piloto do comportamento dos produtos pellet feed, pellet screenings e micro pellet em substituição ao sinter feed em uma mistura de sinterização [dissertação]. Belo Horizonte: Universidade Federal de Minas Gerais; 2004.

4 Gan M, Fan XH, Ji ZY, Chen XL, Yin L, Jiang T, et al. Optimising method for improving granulation effectiveness of iron ore sintering mixture. Ironmaking \& Steelmaking. 20I5;42(5):35I-357.

5 Miwa T, Kurihara K. Iron-Making technology progress in Japan. In: METEC InSteelCon. Plenary Session $6^{\text {th }}$ ECIC; 20II, June 27-July I; Düsseldorf Germany. Düsseldorf; p. 35-43.

6 Umadevi T, Brahmacharyulu A, Roy AK, Maphatra PC, Brabhu M, Ranjan M. Influence of iron ore fines feed size on microstructure, productivity and quakity of iron ore sinter. ISIJ International. 2007;47(3):349-358.

7 Lu L, Holmes J, Manuel JR. Effects of alumina on sintering performance of hematite iron ores. ISIJ International. 20II;57(6):922-929.

8 Cores A, Babich A, Muñiz A, Ferreira S, Mochon J. The influence of different iron ores mixtures composition on the quality of sinter. ISIJ International. 2010;50(8): 1089-1098.

9 Kowalski W, Kersting K, Werner P. The influence of sinter composition on sintering rate and physical quality of sinter. In: The Iron \& Steel Society. 56 ${ }^{\text {th }}$ Iron Making Conference Proceedings; 1997 April 13-16; Chicago. London: IOM3; 1997. p. $415-425$.

$10 \mathrm{Hsieh} \mathrm{LH}$, Whiteman JA. Effect of raw material composition on the mineral phases in lime-fluxed iron ore sinter. ISIJ International. 1993;33(4):462-473.

II Sarna, SK. Factors influencing sintering process [internet]. 2015 [cited 2015 feb. 23]. Available at: http://ispatguru. com/factors-influencing-sintering-process.

I2 International Organization for Standardization. ISO 327 I:2007 - Iron ores for blast furnace and direct reduction feedstocks: determination of tumble strength and abrasion indices. Geneva: ISO; 2007.

13 International Organization for Standardization. ISO 4695:2007 - Iron ores for blast furnace feedstocks: determination of reducibility by the rate of reduction index. Geneva: ISO; 2007.

14 International Organization for Standardization. ISO 4696- I:2007 - Iron ores for blast furnace feedstocks: determination of low-temperature reduction disintegration indices by static method - part I: reaction with $\mathrm{CO}$, $\mathrm{CO}_{2}, \mathrm{H}_{2}$ and $\mathrm{N}_{2}$. Geneva: ISO; 2007.

Received: 5 Aug. 2016

Accepted: 19 Jan. 2017 